\title{
TNIP1 Gene
}

National Cancer Institute

\section{Source}

National Cancer Institute. TNIP1 Gene. NCI Thesaurus. Code C150067.

This gene is involved in the positive regulation of tumor necrosis factor alpha-induced protein 3 (TNFAIP3)-mediated deubiquitination activity. 